\title{
Effectiveness of using Elevit feed additive in pig feeding
}

\author{
Gregory Pokhodnya ${ }^{1}$, Vitaliy Seleznyov ${ }^{1}$, Oksana Popova ${ }^{1}$, Natalya Maslova $^{1 *}$, and Alla
} Khokhlova $^{1}$

${ }^{1}$ Belgorod State Agrarian University named after V.Ya. Gorina, Belgorod, Russia

\begin{abstract}
In a number of experiments, adding of Elevit feed additive in the amount of 100,150,200, or 250 grams per day to the basic ration of breeding boars helps to increase sperm production by $5.0,8.6,11.9$, and $11.1 \%$ in comparison with the control group of boars. In the boars of experimental groups, qualitative parameters of sperm increased as following: sperm resistance by $6.6,8.1,12.3$, and $11.9 \%$; the ability of sperm cell to live outside the body by $6.0,6.7,7.4$, and $8.1 \%$ in comparison with the control group.Adding this drug at the dose of 50,100,150, and $200 \mathrm{~g}$ to the basic diet of sows during the period of their preparation to insemination has a favorable effect on increasing the following parameters: sexual heat by $5.0,10.0,10.0$, and $10.0 \%$; productive insemination by $1.0,7.1,1.9$, and $7.1 \%$; number of piglets in a litter by $2.8,6.6,7.6$, and $5.7 \%$ in comparison with the control group.
\end{abstract}

\section{Introduction}

One of the priority spheres that determine country's development prospects is providing the population with high-quality domestic food products. An important role in solving this problem is played by one of the most effective sectors - pig farming $[1,3,4]$.

Phytogenic feed additives include more than 100 components that are the basis of many active substances, for example, essential oils, medicinal bitters, saponins, flavonoids, and others $[2,6,7,11,12,13,14,15]$.

Increased feeding is an important issue in raising piglets and lactating sows. Increased feed using is important for the development of the gastrointestinal tract of piglets, increasing milk of sows and maximal weight gain in piglets [5,8,9,10,24-27].

It is planned to apply a large range of measures during the implementation of different programs for improving pig farming that are aimed at implementation the best practices of domestic and foreign companies that comply with international standards and provide:

- minimum amount of feed, i.e. not more than $3.5 \mathrm{~kg}$ per $1 \mathrm{~kg}$ of weight gain. It can be achieved with the use of modern equipment and balanced rations;

- applying high-tech equipment in all technological processes (whether it is imported or of domestic origin); it allows automating the production process to the maximum extent, reducing energy costs and creating optimal microclimate parameters in premises;

- the main measure is the use for production of livestock with high genetic potential what ensures a minimum fattening period and maximum growth at minimum expenses;

*Corresponding author: natasha-maslova@mail.ru 
- training highly qualified personnel for work in pig farming; it is an important issue; they should be perfect in applying all the technologies used at the enterprise.

Industrial pig farms, when drawing up diets for pigs and when growing modern highly productive crosses, try to use different balancing feed additives and vitamin preparations which, in turn, help to fully ensure the complete feeding of animals.

OOO Vita company (Belgorod Region) has produced Elevit feed additive based on wheat germ flour.

During this laboratory and production experiment, physiological and biochemical studies were carried out using standard methods.

Studies on the effect of Elevit feed additive on the productive qualities of pigs were carried out by the comparative method of analogous groups; biometric analysis was also used. Reproductive parameters of sows, such as fertility, multiple fetation and size of fetus, were defined by evaluating the actual farrowings.

Live weight was determined on the basis of individual weighing of piglets. All groups of pigs received balanced diets in accordance with the standards of the All-Russian Institute of Animal Husbandry. Sperm from breeding boars-producer was taken using a manual method. Sperm quality was assessed in a routine way. For insemination, the sperm used was diluted with GCCS (glucose, chelate, citrate, sulfate) medium depending on the concentration of motile sperm cells in it.

\section{Results}

The first experiment was carried out in "Gorin Kolkhoz" agricultural production cooperative where the effectiveness of using Elevit feed additive when feeding pigs was studied. 15 Landrace breeding boars at the age of 2.5-3 years were divided by the principle of analogues into five groups (one control group and four experimental ones).

Quantitative parameters of sperm of boars are shown in Table 1.

Table 1. Quantitative parameters of sperm of boars depending on giving them Elevit feed additive.

\begin{tabular}{|c|c|c|c|c|c|c|}
\hline \multirow{2}{*}{ 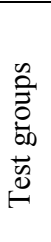 } & \multirow{2}{*}{ Feeding of boars } & \multirow{2}{*}{$\begin{array}{l}\text { Number } \\
\text { of } \\
\text { animals }\end{array}$} & \multirow{2}{*}{$\begin{array}{c}\text { Number } \\
\text { of } \\
\text { ejaculates }\end{array}$} & \multicolumn{3}{|c|}{ Quantitative parameters of boar sperm } \\
\hline & & & & $\begin{array}{c}\text { Sperm volume, } \\
\mathrm{mL}\end{array}$ & $\begin{array}{l}\text { Concentration } \\
\text { of sperm cells } \\
\text { in } 1 \mathrm{~mL} \text { of } \\
\text { sperm, mln }\end{array}$ & $\begin{array}{l}\text { Total number of } \\
\text { sperm cells in } \\
\text { ejaculate, bln }\end{array}$ \\
\hline 1 & Basic diet & 3 & 12 & $303.0 \pm 1.3$ & $183.0 \pm 1.5$ & $54.8 \pm 1.9$ \\
\hline 2 & $\begin{array}{c}\mathrm{BD}+100 \mathrm{~g} \text { of Elevit feed } \\
\text { additive }\end{array}$ & 3 & 12 & $311.0 \pm 1.3$ & $213.0 \pm 1.8$ & $65.8 \pm 1.5$ \\
\hline 3 & $\begin{array}{c}\mathrm{BD}+150 \mathrm{~g} \text { of Elevit feed } \\
\text { additive }\end{array}$ & 3 & 12 & $316.0 \pm 1.2$ & $217.0 \pm 1.5$ & $68.1 \pm 1.4$ \\
\hline 4 & $\begin{array}{c}\mathrm{BD}+200 \mathrm{~g} \text { of Elevit feed } \\
\text { additive }\end{array}$ & 3 & 12 & $319.5 \pm 1.4$ & $221.0 \pm 1.2$ & $70.1 \pm 1.6$ \\
\hline 5 & $\begin{array}{c}\mathrm{BD}+250 \mathrm{~g} \text { of Elevit feed } \\
\text { additive }\end{array}$ & 3 & 12 & $318.0 \pm 1.7$ & $219.6 \pm 1.4$ & $69.5 \pm 1.6$ \\
\hline
\end{tabular}


Zoological hygiene parameters were the same for experimental and control groups, the only differences were in feeding animals. Breeding boars of the first group received standard compound feed K-57-2 in the amount of $3.5 \mathrm{~kg}$ for animal per day. The second, third, fourth, and fifth groups in addition to the basic diet received Elevit feed additive at the dose of 100 , 150, 200, and 250 grams for 1 animal per day, respectively. Elevit feed additive was given to the boars of experimental groups (groups 2-5) during 60 days. 12 ejaculates were obtained from each boar in the course of this period.

Analysis of Table 2 revealed that adding Elevit feed additive in doses of 100, 150, 200, and 250 grams to the main diet increases the volume of ejaculates by $2.6,4.3,5.4$, and $4.9 \%$, respectively.

An increase in sperm concentration by $0.9,2.8,4.7$, and $4.5 \%$ per $1 \mathrm{~mL}$ of sperm was noted for the relevant groups. Total sperm count in the ejaculate also increased by 3.6, 7.2, 10.4 , and $9.4 \%$ in comparison with the control group 1.

Analysis of the data in Table 2 results in the conclusion that using Elevit feed additive leads to better qualitative sperm parameters in breeding boars. So, in experimental groups (groups 2-4), sperm resistance outside the body increased by 5.5, 6.4, 11.8, and 11.6\%, respectively, and viability increased by $9.7,10.4,11.1$, and $13.8 \%$, respectively, in comparison with the control group 1.

Table2. Qualitative parameters of sperm of boars depending on giving them Elevit feed additive.

\begin{tabular}{|c|c|c|c|c|c|}
\hline \multirow[t]{2}{*}{ No. } & \multirow{2}{*}{$\begin{array}{c}\text { Number of } \\
\text { animals }\end{array}$} & \multirow{2}{*}{$\begin{array}{c}\text { Number of studied } \\
\text { ejaculates }\end{array}$} & \multicolumn{3}{|c|}{ Qualitative parameters of sperm } \\
\hline & & & Motility, points & Resistance & $\begin{array}{l}\text { Living outside the } \\
\text { body, hours }\end{array}$ \\
\hline 1 & 3 & 12 & $8.1 \pm 0.01$ & $1,118.0 \pm 60$ & $72.0 \pm 1.2$ \\
\hline 2 & 3 & 12 & $8.1 \pm 0.01$ & $1,180.0 \pm 80$ & $79.0 \pm 1.3$ \\
\hline 3 & 3 & 12 & $8.1 \pm 0.01$ & $1,190.0 \pm 75$ & $79.5 \pm 1.1$ \\
\hline 4 & 3 & 12 & $8.2 \pm 0.01$ & $1,250.0 \pm 60$ & $80.0 \pm 1.2$ \\
\hline 5 & 3 & 12 & $8.2 \pm 0.01$ & $1,248.0 \pm 65$ & $82.0 \pm 1.4$ \\
\hline
\end{tabular}

Thus, results of the studies performed showed a positive trend in the assessment of quantitative and qualitative parameters of sperm of breeding boars when adding Elevit feed additive to their diet.

Effectiveness of using Elevit feed additive in the diets of breeding boars is shown in Table 3.

Table 3. Effectiveness of using Elevit feed additive in boars.

\begin{tabular}{|c|c|c|c|c|c|}
\hline Parameters & \multicolumn{5}{|c|}{ Feeding animals } \\
\cline { 2 - 6 } & Basic diet & $\begin{array}{c}\text { BD }+100 \mathrm{~g} \text { of } \\
\text { Elevit feed } \\
\text { additive }\end{array}$ & $\begin{array}{c}\text { BD+150 g of } \\
\text { Elevit feed } \\
\text { additive } \\
\text { BD + 200 g of } \\
\text { Elevit feed } \\
\text { additive }\end{array}$ & $\begin{array}{c}\text { BD }+250 \mathrm{~g} \text { of } \\
\text { Elevit feed } \\
\text { additive }\end{array}$ \\
\hline $\begin{array}{c}\text { Number of animals, } \\
\text { pcs }\end{array}$ & 3 & 3 & 3 & 3 & 3 \\
\hline $\begin{array}{c}\text { Duration of } \\
\text { experiment, days }\end{array}$ & 60 & 60 & 60 & 60 & 60
\end{tabular}




\begin{tabular}{|c|c|c|c|c|c|}
\hline $\begin{array}{c}\text { Expenses for 1 } \\
\text { animal per period, } \\
\text { RUR }\end{array}$ & $3,601.0$ & $3,601.0$ & $3,601.0$ & $3,601.0$ & $3,601.0$ \\
\hline $\begin{array}{c}\text { Cost of Elevit per 1 } \\
\text { animal, RUR }\end{array}$ & 0 & 485.0 & 725.0 & 965.0 & $1,205.0$ \\
\hline $\begin{array}{c}\text { Sperm doses } \\
\text { obtained from 1 boar }\end{array}$ & 178 & 2132 & 221 & 228 & 228 \\
\hline $\begin{array}{c}\text { Cost of 1 sperm } \\
\text { dose, RUR }\end{array}$ & 20.46 & 19.16 & 19.85 & 19.79 & 21.40 \\
\hline
\end{tabular}

Assessing economic parameters in Table 3, we can conclude that using Elevit feed additive in the amount of $100,150,200$, and 250 grams in addition to the daily ration of breeding boars contributes to an increase in sperm doses per 1 male by $19.6,23.5,28.6$, and $27.5 \%$, respectively, for the studied groups.

The cost of 1 sperm dose was the lowest in group II when boars were given Elevit feed additive in the amount of $100 \mathrm{~g}$ in addition to the basic ration. It also should be noted that with the increase in the amount of Elevit feed additive from 100 grams to 200 grams, the number of sperm doses increased by $19.6-28.6 \%$, and their cost increased at the same time but in these cases it did not exceeded this of the control group.

Using Elevit feed additive in the amount of 250 grams in addition to the daily diet led to the fact that the cost of 1 sperm dose exceeded this of control group by $4.5 \%$ despite the fact that the number of sperm doses in group 5 was $27.5 \%$ higher than in the control group 1 . This is obviously caused by the increasing cost of the diet of boars due to the increase in Elevit feed additive by $33 \%$ when compared with the control group 1 .

The second experiment was carried out on replacement gilts; 100 animals were selected for this test. According to the principle of analogues, this population was divided into 5 groups. The age of these pigs was 8 months. Feeding conditions for replacement gilts were different, and keeping conditions were the same. Group 1 received basic diet according to the standards of the All-Russian Institute of Animal Husbandry.

Groups 2-5 were given Elevit feed additive at the dose of 50, 100, 150, and $200 \mathrm{~g}$, respectively, in addition to $\mathrm{BD}$.

The preparation was used in this age-sex group until signs of sexual heat appeared. This period was no more than 20 days. Gilts with the signs of heat within 21 days were transferred to an artificial insemination department (Table 4).

Table 4. Results of the effect of Elevit on the sexual heat of gilts.

\begin{tabular}{|c|c|c|c|c|}
\hline No. & Feeding gilts & $\begin{array}{c}\text { Number of } \\
\text { animals }\end{array}$ & \multicolumn{2}{|c|}{ Gilts with the signs of sexual heat during 21 days } \\
\cline { 3 - 5 } & Basic diet & 20 & number & $\%$ \\
\hline 1 & 20 & 14 & 70.0 \\
\hline 2 & $\begin{array}{c}\text { BD+100 g of Elevit } \\
\text { feed additive }\end{array}$ & 20 & 19 & 80.0 \\
\hline 3 & $\begin{array}{c}\text { BD+150 g of Elevit } \\
\text { feed additive }\end{array}$ & \begin{tabular}{c}
$|c|$ \\
\hline
\end{tabular}
\end{tabular}




\begin{tabular}{|c|c|c|c|c|}
\hline 4 & $\begin{array}{c}\text { BD+200 g of Elevit } \\
\text { feed additive }\end{array}$ & 20 & 19 & 95.0 \\
\hline 5 & $\begin{array}{c}\text { BD+250 g of Elevit } \\
\text { feed additive }\end{array}$ & 20 & 19 & 95.0 \\
\hline
\end{tabular}

Table 4 demonstrate the values obtained. Gilts that were given Elevit feed additive in the amount of 50,100, 150, and $200 \mathrm{~g}$ showed increase of sexual heat by 10.0, 25.0, 25.0, and $25.0 \%$, respectively.

Effectiveness of using Elevit feed additive in young sows and results of insemination are shown in Table 5.

Data in Table 5 show that giving Elevit feed additive to replacement gilts in the amount of 50,100,150, and $200 \mathrm{~g}$ in addition to the main diet increases reproductive functions as following: fertility by $3.6,7.5,7.5$, and $7.5 \%$, respectively; multiple fetation by $2.1,5.4,5.4$, and $5.4 \%$, respectively. Fetus size in all groups of replacement gilts was similar and had no reliable differences.

Using Elevit additive during their preparation for insemination has a positive effect on the increase of sexual heat signs and reproductive function in gilts.

Table 5. Result of using Elevit feed additive in young sows.

\begin{tabular}{|l|c|c|c|c|c|c|c|}
\hline No. & \multirow{2}{*}{$\begin{array}{c}\text { Feeding } \\
\text { animals }\end{array}$} & \multirow{2}{*}{$\begin{array}{c}\text { Number } \\
\text { of sows }\end{array}$} & \multicolumn{2}{|c|}{$\begin{array}{c}\text { From them } \\
\text { farrowed }\end{array}$} & \multicolumn{2}{|c|}{ Total piglets, pcs } & \multirow{2}{*}{ Fetus size, kg } \\
\cline { 4 - 7 } & & $\begin{array}{c}\text { numb } \\
\mathrm{er}\end{array}$ & $\%$ & total & per 1 litter & \\
\hline 1 & Basic diet & 14 & 10 & 71.4 & 91 & $9.1 \pm 0.1$ & $1.25 \pm 0.01$ \\
\hline 3 & $\begin{array}{c}\text { BD+50 g of } \\
\text { Elevit }\end{array}$ & 16 & 12 & 75.0 & 112 & $9.3 \pm 0.1$ & $1.24 \pm 0.02$ \\
\hline 4 & $\begin{array}{c}\text { BD+100 g of } \\
\text { Elevit }\end{array}$ & 19 & 15 & 78.9 & 145 & $9.6 \pm 0.1$ & $1.24 \pm 0.01$ \\
\hline 5 & $\begin{array}{c}\text { BD+150 g of } \\
\text { Elevit }\end{array}$ & 19 & 15 & 78.9 & 144 & $9.6 \pm 0.1$ & $1.23 \pm 0.02$ \\
\hline Elevit & 19 & 15 & 78.9 & 145 & $9.6 \pm 0.1$ & $1.24 \pm 0.01$ \\
\hline
\end{tabular}

Positive changes in obtaining piglets could be noted when adding Elevit feed additive in the amount of 100-200 $\mathrm{g}$ to the basic diet of young sows.

Economic effectiveness of using Elevit feed additive in the diets of replacement gilts is shown in Table 6.

Table 6. Economic effectiveness of using Elevit feed additive.

\begin{tabular}{|l|c|c|c|c|c|}
\hline \multicolumn{1}{|c|}{$\begin{array}{c}\text { Parameter } \\
\text { s }\end{array}$} & \multicolumn{5}{|c|}{ Conditions of feeding } \\
\cline { 2 - 6 } & Basic diet & $\begin{array}{c}\text { BD+50 g of } \\
\text { Elevit }\end{array}$ & $\begin{array}{c}\text { BD+100 g of } \\
\text { Elevit }\end{array}$ & $\begin{array}{c}\text { BD+150 g of } \\
\text { Elevit }\end{array}$ & $\begin{array}{c}\text { BD+200 g of } \\
\text { Elevit }\end{array}$ \\
\hline $\begin{array}{l}\text { Number of } \\
\text { animals, pcs }\end{array}$ & 20 & 20 & 20 & 20 & 20 \\
\hline $\begin{array}{l}\text { Number of } \\
\text { gilts in heat } \\
\text { during 21 } \\
\text { days, pcs }\end{array}$ & 14 & 16 & 19 & 19 & 19 \\
\hline $\begin{array}{l}\text { Farrowed } \\
\text { females, pcs }\end{array}$ & 10 & 12 & 15 & 15 & 15 \\
\hline $\begin{array}{l}\text { Multiple } \\
\text { fetation, pcs }\end{array}$ & 9.10 & 9.30 & 9.60 & 9.60 & 9.60 \\
\hline
\end{tabular}




\begin{tabular}{|l|c|c|c|c|c|}
\hline $\begin{array}{l}\text { Total piglets, } \\
\text { pcs }\end{array}$ & 91 & 112 & 145 & 144 & 145 \\
\hline $\begin{array}{l}\text { Expenses per } \\
\text { sow, RUR }\end{array}$ & $96,006.0$ & $96,006.0$ & $96,006.0$ & $96,006.0$ & $96,006.0$ \\
\hline $\begin{array}{l}\text { Expenses for } \\
\text { additive, RUR }\end{array}$ & 0 & 800.0 & $1,600.0$ & $2,400.0$ & $3,200.0$ \\
\hline $\begin{array}{l}\text { Total } \\
\text { expenses for } \\
\text { piglets } \\
\text { obtained, } \\
\text { RUR }\end{array}$ & $96,006.0$ & $9,686.00$ & $97,606.00$ & $98,406.00$ & $99,206.00$ \\
\hline $\begin{array}{l}\text { Cost of 1 } \\
\text { piglet at birth, } \\
\text { RUR }\end{array}$ & $1,057.95$ & 867.29 & 674.11 & 684.34 & 683.14 \\
\hline $\begin{array}{l} \pm \quad \text { to the } \\
\text { control group, } \\
\text { RUR to the }\end{array}$ & - & -190.65 & -381.83 & -371.60 & -370.80 \\
\hline $\begin{array}{l} \pm \quad \text { to } \\
\text { control group, } \\
\% \text { - }\end{array}$ & -18.01 & -36.12 & -35.21 & -35.12 \\
\hline
\end{tabular}

Results in Table 6 demonstrate the positive trend: giving Elevit feed additive to replacement gilts in the process of preparing them for insemination in the amount of 50,100, 150 , and $200 \mathrm{~g}$ per 1 animal in addition to their daily ration has increased their sexual heat by $10.0,25.0,25.0$, and $25.0 \%$, respectively. Reproductive rates increased as follows: fertility by $3.6,7.5,7.5$, and $7.5 \%$, respectively; multiple fetation by $2.1,5.4,5.4$, and $5.4 \%$, respectively; finally, it contributed to an increase in the total number of obtained piglets by 23.0, 59.3, 58.2, and 59.3\%, respectively.

The final result influenced the cost of animals at birth; it decreased by $190.66,381.84$, 371.61 , and 370.81 RUR, or 18.0, 36.1, 35.2, and 35.1\%, respectively, in comparison with the control group.

The third experiment was conducted on sows; 100 animals were selected for this test. According to the principle of analogues, this population was divided into 5 groups. The age of these pigs was 2.5-3 years, after weaning piglets at 28 days.

Animals after being transferred to the reproduction department were in similar keeping conditions; the only differences were in the composition of diet. Group 1 received basic diet according to the standards of the All-Russian Institute of Animal Husbandry.

Groups 2-5 were given Elevit feed additive at the dose of 50, 100, 150, and $200 \mathrm{~g}$, respectively, in addition to BD. Preparation was used in this age-sex group until signs of sexual heat appeared. This period was no more than 20 days. Animals with the signs of heat within 21 days were transferred to an artificial insemination department (table 7).

Table 7. Effect of giving a feed additive to adult sows on the effectiveness of their insemination.

\begin{tabular}{|c|c|c|c|c|c|c|c|}
\hline \multirow{2}{*}{ 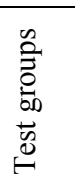 } & \multirow[t]{2}{*}{$\begin{array}{l}\text { Conditions of } \\
\text { feeding sows }\end{array}$} & \multirow{2}{*}{$\begin{array}{l}\text { Number } \\
\text { of } \\
\text { inseminat } \\
\text { ed sows }\end{array}$} & \multicolumn{2}{|c|}{$\begin{array}{l}\text { From them - } \\
\text { farrowed }\end{array}$} & \multicolumn{2}{|c|}{ Piglets obtained, pcs } & \multirow{2}{*}{$\begin{array}{l}\text { Fe } \\
\text { tus } \\
\text { size, } \\
\mathrm{kg}\end{array}$} \\
\hline & & & number & $\%$ & total & $\begin{array}{l}\text { per } 1 \\
\text { litter }\end{array}$ & \\
\hline 1 & Basic diet & 17 & 14 & 82.3 & 148 & $10.5 \pm 0.1$ & 1.25 \\
\hline 2 & $\begin{array}{l}\mathrm{BD}+50 \mathrm{~g} \text { of } \\
\text { Elevit }\end{array}$ & 18 & 15 & 83.3 & 163 & $10.8 \pm 0.1$ & 1.24 \\
\hline 3 & $\mathrm{BD}+100 \mathrm{~g}$ of & 19 & 17 & 89.4 & 191 & $11.2 \pm 0.1$ & 1.25 \\
\hline
\end{tabular}




\begin{tabular}{|c|c|c|c|c|c|c|c|}
\hline & Elevit & & & & & & \\
\hline 4 & $\begin{array}{c}\text { BD+150 g of } \\
\text { Elevit }\end{array}$ & 19 & 17 & 89.4 & 190 & $11.1 \pm 0.1$ & 1.27 \\
\hline 5 & $\begin{array}{c}\text { BD+200 g of } \\
\text { Elevit }\end{array}$ & 19 & 17 & 89.4 & 189 & $11.1 \pm 0.1$ & 1.26 \\
\hline
\end{tabular}

Sows with the signs of heat within 21 days were transferred to an artificial insemination department; they were inseminated twice, first time immediately after sampling and once again, in 24 hours.

Adding Elevit feed additive in the amount of 50, 100, 150, and $200 \mathrm{~g}$ to BD of adult females after weaning offspring led to an increase in their sexual heat by 5.0, 10.0, 10.0, and $10.0 \%$, respectively.

Results in Table 7 demonstrate the positive trend: giving Elevit feed additive to sows in the process of preparing them for insemination in the amount of 50,100, 150, and $200 \mathrm{~g}$ per 1 animal in addition to their daily diet increased their reproductive parameters as follows: fertility of sows by $1.0,7.1,7.1$, and $7.1 \%$, respectively; multiple fetation by $2.8,6.6,5.7$, and $11.1 \%$ respectively.

Using Elevit for feeding sows results in better transfer of nutrients and energy from feed into milk and in reduced risk of additional loss of live weight by lactating animals.

The greatest positive result, i.e. the maximum number of piglets at birth, was achieved by using Elevit feed additive in the amount of 100-200 g per 1 adult sow.

Final conclusion about the optimal dose of Elevit feed additive for sows can be made by analyzing economic efficiency; the information is shown in Table 8.

Table 8. Economic effectiveness of using Elevit feed additive on the signs of sexual heat in sows.

\begin{tabular}{|l|c|c|c|c|c|}
\hline \multirow{2}{*}{ Parameters } & \multicolumn{5}{|c|}{ Conditions of feeding sows } \\
\cline { 2 - 6 } & Basic diet & $\begin{array}{l}\text { BD +50 gof } \\
\text { Elevit feed } \\
\text { additive }\end{array}$ & $\begin{array}{l}\text { BD + 100 g } \\
\text { of Elevit } \\
\text { feed additive }\end{array}$ & $\begin{array}{l}\text { BD + 150 g } \\
\text { of Elevit } \\
\text { feed additive }\end{array}$ & $\begin{array}{l}\text { BD + 200 g } \\
\text { of Elevit } \\
\text { feed additive }\end{array}$ \\
\hline $\begin{array}{l}\text { Number of } \\
\text { animals, pcs }\end{array}$ & 20 & 20 & 20 & 20 & 20 \\
\hline $\begin{array}{l}\text { Number of sows } \\
\text { with the signs of } \\
\text { sexual heat during } \\
\text { 21 days }\end{array}$ & 17 & 18 & 19 & 19 & 19 \\
\hline $\begin{array}{l}\text { Number of } \\
\text { farrowing sows }\end{array}$ & 14 & 15 & 17 & 17 & 17 \\
\hline $\begin{array}{l}\text { Total piglets } \\
\text { obtained, pcs }\end{array}$ & 148 & 163 & 191 & 190 & 189 \\
\hline $\begin{array}{l}\text { Expenses for } \\
\text { keeping 20 sows } \\
\text { for 120 days, } \\
\text { RUR }\end{array}$ & $9,606.0$ & $9,606.0$ & $9,606.0$ & $9,606.0$ & $9,606.0$ \\
\hline $\begin{array}{l}\text { Expenses for } \\
\text { Elevit feed } \\
\text { additive, RUR }\end{array}$ & 0 & 805.0 & $1,605.0$ & $2,405.0$ & $3,205.0$ \\
\hline $\begin{array}{l}\text { Total expenses for } \\
\text { piglets obtained, } \\
\text { RUR }\end{array}$ & $96,000.0$ & $96,805.0$ & $97,605.0$ & $98,405.0$ & $99,205.0$ \\
\hline $\begin{array}{l}\text { Cost of 1 piglet at } \\
\text { birth, RUR }\end{array}$ & 649.64 & 594.86 & 511.99 & 518.89 & 525.86 \\
\hline $\begin{array}{l}- \text { in comparison } \\
\text { with the first } \\
\text { group, RUR }\end{array}$ & 0 & -54.78 & -137.65 & -130.75 & -123.78 \\
\hline
\end{tabular}


Data in Table 8 show that the adding Elevit feed additive in the amount of 50, 100, 150, and $200 \mathrm{~g}$ to the diet of sows during the period or preparing them for insemination led to the increase of their fertility, multiple fetation, and also has a positive effect on their sexual heat.

It finally led to the fact that the total number of piglets obtained also increased by 10.1 , $29.0,28.3$, and $27.7 \%$, respectively. Cost of piglets at birth decreased slightly by 54.78 , $137.65,130.75$, and 123.64 RUR. If this is expressed as a percentage, then it amounts to 8.4, 21.2, 20.1, and $19.0 \%$ in comparison with the control group 1 .

Analysis of the abovementioned material reveals that adding Elevit feed additive to the diet of sows in the period of their preparation for insemination brings positive results.

\section{Conclusions}

Analysis of the results obtained revealed that using Elevit feed additive in pigs gave a positive effect. But it should be noted that the best results in the terms of productivity and economic efficiency were obtained at the following doses: for breeding boars $-100 \mathrm{~g}$ in addition to the basic diet, for replacement and adult sows during their preparation for insemination -100 grams in addition to the basic diet, for piglets during growing period from 1 to 3 months -10 grams per day per 1 animal in replacement of compound feed, for piglets in fattening period $-1.0 \%$ in addition to the basic diet during 30 days from 4 to 5 months.

\section{References}

1. N. Belousov, Pig farming, 4, 11-12 (2019)

2. L.N. Gamko, Pig farming, 5, 25-26 (2019)

3. V.Ya. Gorin, G.S. Pokhodnya, A.A. Fainov, E.G. Fedorchuk, A.N. Ivchenko, T.A. Malakhova, Zootechnics, 5, 24-26 (2014)

4. V.Ya. Gorin, N.I. Karpenko, V.M. Borzenkov, A.A. Fainov, G.S. Pokhodnya, Organization and technology of pork production, 704 (Belgorod: "Vezelitsa" Publishing House, 2011)

5. V.Ya. Gorin, A.A. Fainov, G.S. Pokhodnya, E.G. Fedorchuk, T.A. Malakhova, Zootechnics, 5, 21-23 (2014)

6. D.V. Korobov, G.S. Pokhodnya, O.E. Tatyanicheva, T.A. Malakhova, O.A. Popova, Innovative Solutions in Agricultural Science: Looking into the Future, 2, 31-33 (2019)

7. N.A. Maslova, A.P. Khokhlova, Effectiveness of use Kormo-Tox Plus feed additive in the diets of birds, Materials of the XXIII International Scientific and Industrial Conference "Innovative Solutions in Agricultural Science: Looking into the Future", 2 , 49-50 (Maisky v.: Publishing House of Federal State Budgetary Educational Institution of Higher Education "Belgorod State Agrarian University", 2019)

8. N.A. Maslova, A.P. Khokhlova, Intensification of reproductive function in sows: monograph, 201 (Belgorod: Belgorod Regional Printing House, 2014)

9. S.P. Moskalenko, Pig farming, 8, 39-41, 2019

10. T.A. Malakhova, G.S. Pokhodnya, Bulletin of the Krasnoyarsk State Agrarian University, 9, 175-180 (2015)

11. K.V. Niemelya, V. Chupasov, Pig farming, 4, 30 (2019)

12. E. Nikolayeva, Animal husbandry in Russia, 9, 18-22 (2019)

13. G.S. Pokhodnya, Pig farming and pork production technology, 776 (Belgorod: Vezelitsa, 2009)

14. O.A. Popova, O.E. Tatyanicheva, A.A. Popov, T.N. Khokhlova, Topical Issues of Agricultural Biology, 3 (13), 58-63 (2019)

15. O.A. Popova, O.E. Tatyanicheva, Topical Issues of Agricultural Biology, 2 (8), 36-40 (2018) 
16. G.S. Pokhodnya E.G. Fedorchuk, T.A. Malakhova, O.N. Tarasov, Bulletin of the Kursk State Agricultural Academy, 8, 15-18 (2017)

17. G.S. Pokhodnya, T.A. Malakhova, O.N. Tarasov, Topical Issues of Agricultural Biology, 2 (4), 24-29 (2017)

18. G.S. Pokhodnya, P.P. Kornienko, N.S. Trubchaninova, M.R. Shvetsova, Organization of breeding in pig farming, 47 (Belgorod: Publishing House of the Federal State Budgetary Educational Institution of Higher Education "Belgorod State Agrarian University", 2017)

19. G.S. Pokhodnya, T.A. Malakhova, Agrarian Science, 7-8, 32-34 (2018)

20. G.S. Pokhodnya, Innovative solutions in agricultural science: looking into the future, Materials of the XXIII International Scientific and Industrial Conference "Innovative solutions in agricultural science: looking into the future" 1, (2019)

21. G.S. Pokhodnya, E.G. Fedorchuk, T.A. Malakhova, N.S. Trubchaninova, Yu. P. Breslavets, Research Journal of Pharmaceutical, Biological and Chemical Sciences, 9 (5), 2281-2291 (2018)

22. G. Pokhodnya, T. Malakhova, N. Zhernakova, A.Sergienko "Efficiency of Growing Pigs with Introduction of the Feed Additive "Elevit" into their Ration", 1st International Symposium Innovations in Life Sciences (ISILS 2019), 246-249 (2019)

23. A.V. Sergienko, G.S. Pokhodnya, O.E. Tatyanicheva, Elevit feed additive increases growth and efficiency of growing piglets, Materials of International Student Scientific Conference "Gorinsky Scientific Conference. Researches of young scientists - to the innovative development of agricultural business", 50 (Maisky v.Publishing house of Federal State Budgetary Educational Institution of Higher Education "Belgorod State Agrarian University", 2019)

24. 24. A.P. Khokhlova, D.A. Lobkov, Ways to increase the reproductive function of sows, Materials of International Student Scientific Conference, 108 (2017)

25. A.P. Khokhlova, A.A. Danilov, Meat productivity of experimental piglets of different genotypes, Materials of International Student Scientific Conference "Youth Agricultural Forum-2018." Volume 1. Maysky v: Publishing House of Federal State Budgetary Educational Institution of Higher Education "Belgorod State Agrarian university",148 (2018)

26. N.N. Shvetsov, G.S. Pokhodnya, S.P. Salamakhin, Livestock farming of Russia, 10, 4344 (2009)

27. S. Shelamov, N. Sadovnikova, Live yeast in pig diets. Effect of S. cerevisiae var. boulardii on using feed energy, Animal husbandry of Russia, 36-37 (2019) 